\section{In Vitro Microbiological Analysis of Bacterial Seal at the Implant- Abutment Interface Using Two Morse Taper Implant Models}

Deceles Cristina Costa Alves ${ }^{1}$, Paulo Sérgio Perri de Carvalho ${ }^{1}$, Elizabeth Ferreira Martinez ${ }^{2}$

\author{
'São Leopoldo Mandic Institute and \\ Research Center, Campinas, SP, Brazil \\ ${ }^{2}$ Department of Pathology, São \\ Leopoldo Mandic Institute and \\ Research Center, Campinas, SP, Brazil \\ Correspondence: Dra. Deceles Cristina \\ Costa Alves, Rua Clemente Faria, \\ 181, Centro, 34505-370 Sabará, \\ MG, Brasil. Tel.: +55-31-3671- \\ 1000. e-mail : dcca@terra.com.br
}

The objective of this study was to evaluate the bacterial seal at the implant-abutment interface using two morse taper implant models, by means of an in vitro microbiological analysis. For that were used 15 implants with mini-abutments tightened by friction, no screws (Group 1); and 30 implants with screw-tightened abutments, of which 15 received 20 N.cm of closing torque (Group 2) and the other 15 received 30 N.cm (Group 3). Microbiological analysis was carried out using colonies of Escherichia coli transported directly from a culture dish to the prosthetic component. Friction implants (Group 1) were activated by tapping and a torque wrench was used for screw-tightened implants (Groups 2 and 3). Each abutment/implant set was immersed in test tubes containing $5 \mathrm{~mL}$ of brain-heart infusion broth and incubated at $37^{\circ} \mathrm{C}$ for 14 days, observed daily for the presence of contamination. A statistically significant difference was observed regarding the number of contaminated implants. There was greater contamination in Group 2 implants $(p<0.05)$, with no statistically significant difference between the other groups (Group $1=20 \%$ and Group $3=0 \%$ ). It was concluded that there was no significant difference in in vitro bacterial sealing between implants with mini-abutments tightened by friction without screws and implants with screw-tightened abutments with $30 \mathrm{~N} . \mathrm{cm}$ of closing torque. The difference in closing torque altered the in vitro sealing ability of the tested abutments, with a greater contamination for components that received a closing torque of 20 N.cm.
Key Words: microbiological analysis, morse taper implants, abutment/implant connection.

\section{Introduction}

For many years, Implantology research focused basically on the bone interface and also on the longterm functional load capacity of the implants. However, because most systems consist of two-piece implants, frequent cases of peri-implantitis occurred associated with bacterial colonization in the abutment/implant connection, independent of adequate osseointegration (1-3).

Like the gingiva, the peri-implant mucosa creates a first-shaped barrier attached to the implant surface, which blocks the movement of bacteria and oral toxins in the space between the implant and biological tissues, sealing the region. Any damage to the junctional epithelium can lead to a loss of protective ability and continuous bone loss around the implant $(2,3)$.

It has been suggested that the role of the microorganisms is a factor that may be considered in long term implant survival. The microscopic space caused by the misfit between implant and prosthetic component (microgap) facilitates the infiltration of fluids and macromolecules from tissue fluids and saliva, facilitating bacterial invasion and proliferation (4-6), even in patients with good oral hygiene (7).
Bacterial permeability in the prosthetic abutment/ implant connection, which has been studied by several researchers, allows the exchange of fluids and bacteria between the inner part of the implant and the oral environment (8-11).

In vitro studies have suggested that bacterial contamination through the prosthetic abutment/implant connections may be eventually correlated with gap sizes or misfits. The level of contamination varies or depends not only on the precision of fit, but also on the degree of the applied micromovement and torque. The incidence of loads and unscrewing of the prosthetic abutment can increase infiltration, whereas optimal adaptation, minimal micromovement and exceptional prosthetic and occlusal planning are factors that can prevent or minimize microleakage $(6,12,13)$.

Chewing can also reduce component stability, favoring bacterial infiltration into internal spaces of the implant. Consequently, a mechanism of pumping fluids between the implants and external environments may occur when the implants are submitted to functional loads, thereby increasing the concentration of bacterial metabolites in the peri-implant region $(6,12)$. 
In this sense, it may be assumed that the role of the abutment/implant connection, with regard to the accurate fit between components and mechanical stability, is of considerable importance for long-term therapeutic success. The search for new designs aiming to minimize the presence of microgap and its effects, led to the introduction of morse taper implants as a promising alternative.

Some studies have demonstrated the superiority of morse taper connections when submitted to axial and lateral loads, providing stability in the long term. It has been reported as a safe and reliable coupling, and also as an important factor to achieve stability of the bone crest and implant-supported restorations, due to microgap reduction with lower chance of bacterial contamination (14-18).

In this study, an in vitro microbiological analysis was performed to evaluate comparatively morse taper implants tightened by friction (no screws) and screw-tightened abutments, under two torque situations, with regard to their bacterial seal at the implant-abutment interface.

\section{Material and Methods}

The study was carried out after approval by the Ethics Committee of the São Leopoldo Mandic Institute and Research Center, Brazil (Registration \#2009/0255).
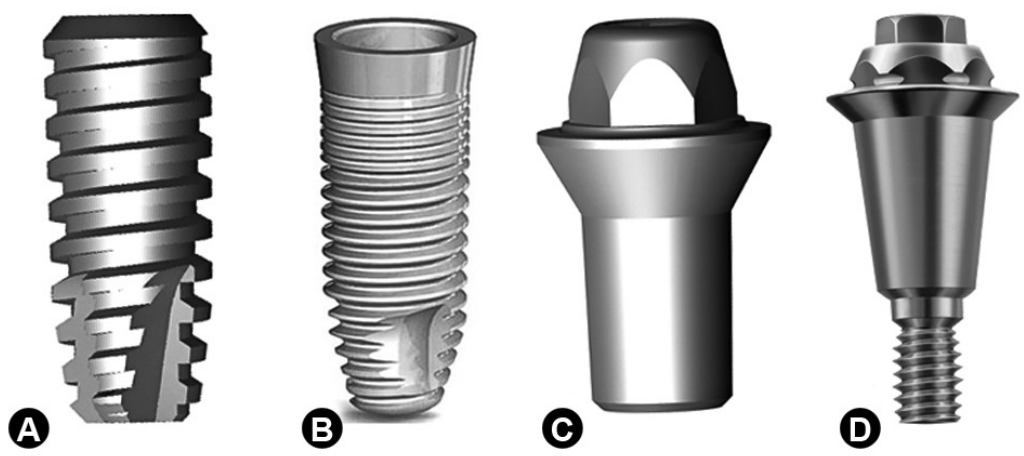

Figure 1. Morse taper implants and abutments. A: frictional implant 11 (Kopp) (Group 1); B: screw-tightened implant master AR Morse Porous (Conexão) (Groups 2 and 3); C: mini-abutment Rll (Kopp) (Group 1); D: microunit abutment (Conexão) (Groups 2 and 3).

Table 1. Implants and abutments used

\begin{tabular}{|c|c|c|c|c|}
\hline Manufacturer & Implant & Lot & Abutment & Lot \\
\hline $\begin{array}{l}\text { Kopp, Curitiba, PR, } \\
\text { Brazil (Group 1) }\end{array}$ & $\begin{array}{l}\text { Frictional Implant } \\
11 \text { Kopp (4.3X11) }\end{array}$ & 1598 & $\begin{array}{l}\text { Mini-Abut. } \\
\text { Rll 3mm }\end{array}$ & 1257 \\
\hline $\begin{array}{l}\text { Conexão, Arujá, } \\
\text { SP, Brazil } \\
\text { (Group 2) }\end{array}$ & $\begin{array}{c}\text { Screw-tightened } \\
\text { lmplant Master AR } \\
\text { Morse Porous (4X10) }\end{array}$ & 31250053 & $\begin{array}{l}\text { Micro-Unit } \\
2.5 \mathrm{~mm}\end{array}$ & 31840055 \\
\hline $\begin{array}{l}\text { Conexão, Arujá, } \\
\text { SP, Brazil } \\
\text { (Group 2) }\end{array}$ & $\begin{array}{c}\text { Screw-tightened } \\
\text { Implant Master AR } \\
\text { Morse Porous (4X10) }\end{array}$ & 107177 & $\begin{array}{l}\text { Micro-Unit } \\
2.5 \mathrm{~mm}\end{array}$ & 108281 \\
\hline
\end{tabular}

Two morse taper implants were evaluated. The implants were used with their respective prosthetic abutments from each model and manufacturers are presented in Table 1.

For the microbiological analysis, were formed used one group with 15 sets of frictional/prosthetic abutment implants (Group 1) and two groups with 15 sets each of screw-tightened/prosthetic abutment implants (Groups 2 and 3), as seen in Figure 1. Three sets from each model were used as negative control and three implants without abutments served as a positive control. All materials were provided by the manufacturers in their original sterile packaging. In a pilot study were tested the contamination method to be used, the method to control external contamination, the implant setting mechanism, the torque to be employed and the period required to evaluate the results.

All procedures were carried out under sterile conditions in a laminar flow chamber, previously disinfected and covered, with the operator adequately equipped to preserve the sterile field. Each prosthetic abutment was first contaminated with strains of Escherichia coli bacteria (ATCC 25922). Prior to use, they were kept frozen and were activated in Brain-Heart Infusion (BHI, Himedia, Mumbai, India) culture medium, kept for $24 \mathrm{~h}$ in a bacteriological incubator at $37{ }^{\circ} \mathrm{C}$ under aerobiosis conditions. After this, a portion of the culture medium was collected using a platinum loop and re-plated in a Petri dish containing $\mathrm{BHI}$ agar (Oxoid, Hampshire, UK), to induce $E$. coli strains growth under the same conditions as previously described.

Solid colonies grown on agar were moved straight from the culture dish to the prosthetic abutment. The most apical portion or the base of the mini-abutment of frictional implants was contaminated, while for screwtightened implants was contaminated the most apical portion of the miniabutment screw. Tips made from previously sterilized orthodontic wire were used, with the proper care not to contaminate implant external surfaces and platforms. The same trained operator manipulated all the samples.

Each abutment was immediately adapted to the corresponding implant. Frictional implants were activated using a beat-connection device or hammer according to manufacturer's 
recommendations. In screw-tightened implants, the recommended torque wrench was used, coupled to a manual torque meter. In Group 2, a closing torque of 20 N.cm was applied, according to manufacturer's specifications, while a 30 N.cm torque was applied in Group 3.

To fix and stabilize the implants two support bases were devised, pre-made in brass. After molding, each support received a final hexagonal configuration, measuring 1.2 $\mathrm{cm}$ high and $1.9 \mathrm{~cm}$ between faces of the hexagon, with one perforation at the center to hold the implants. One of the supports was drilled to receive implants measuring 11 $\mathrm{mm}$ long by $4.3 \mathrm{~mm}$ diameter (Group 1), and the other for implants $10 \mathrm{~mm}$ long by $4 \mathrm{~mm}$ diameter (Groups 2 and 3 ). Implant stabilization was provided by a screw which, placed laterally in one face of the support, pressed the implant against the inner lateral wall of the implant, effectively locking it into place (Fig. 2) .

These supports also fit onto another base that prevented movement during torque application or activation of the prosthetic abutments. That base was built in chrome steel, measuring $19.5 \mathrm{~cm}$ long $\times 2.4 \mathrm{~cm}$ wide $\times 0.5 \mathrm{~cm}$ thick. A hexagonal section was made at one of its extremities, measuring $1.95 \mathrm{~cm}$ from one face to another, in order to were both autoclaved and always used aseptically to avoid contaminating the external portion of the implants.

Each abutment/implant set was placed in a test tube
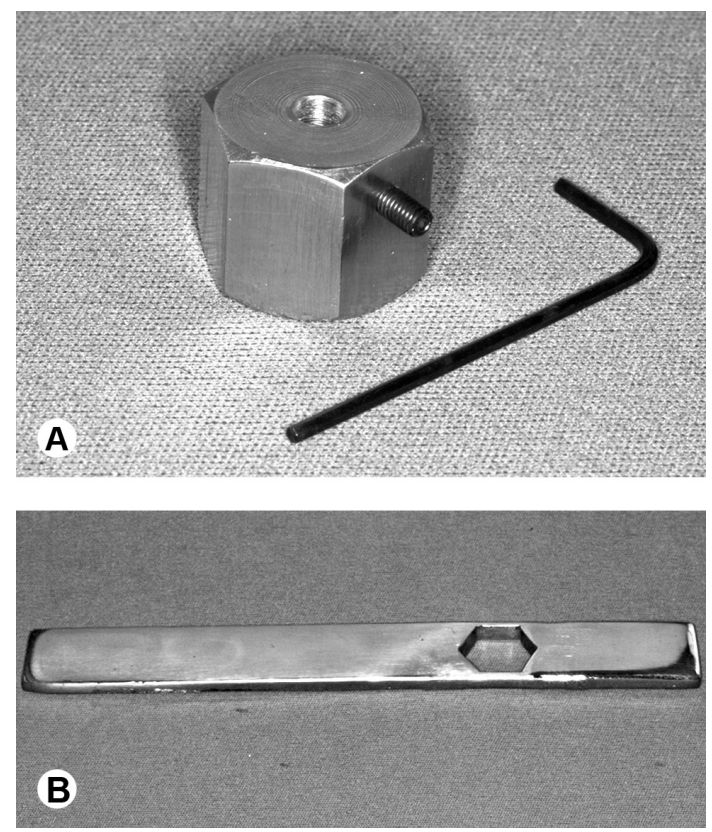

Figure 2. Devised supports to fix and stabilize the implants. A: Hexagonal configuration to fix the implants and apply the torque activation; B: Brass base to prevent movement during torque application of the prosthetic abutments.

containing $5 \mathrm{~mL} \mathrm{BHI} \mathrm{broth.} \mathrm{All} \mathrm{tubes} \mathrm{were} \mathrm{identified} \mathrm{and}$ to assure non-contamination of the external portion, prior to submerging the implants in $\mathrm{BHI}$ broth, each set was scrubbed with a microbrush soaked in $0.9 \%$ sterile saline thoroughly on the surface of the abutment/ implant connection. After this, each microbrush was also immersed in the culture medium, as a control for external contamination.

As a positive control group, three implants of each studied model were contaminated with strains of $E$. coli, under the same conditions described previously, and immersed in BHI without the abutment connection, following the same criteria.

Three other implants, also from each model, were not contaminated, and were incubated sterile from their packaging with attached prosthetic components, for negative control.

All tubes were stored vertically in a rack and taken to the bacteriological incubator for 14 days at $37{ }^{\circ} \mathrm{C}$ under aerobic conditions. They were monitored every $24 \mathrm{~h}$ to observe evidence of bacterial growth, which is macroscopically characterized by clouding of the culture broth or sediment at the bottom of the tubes, indicating the inability of the abutment/implant connection to block the passage of bacteria from inside the implant to the culture medium (Fig. 3).

For confirmation of bacterial growth, portions of the culture medium contained in the tube $(10 \mu \mathrm{L})$ were collected, plated in $\mathrm{BHI}$ agar and incubated at $37^{\circ} \mathrm{C}$ for $24 \mathrm{~h}$.

Following the 24-h culture period and observing colony-forming units (CFUs), each plate was Gram-stained. All slides were viewed under an optical microscope (Zeiss Microscope, Jena, Germany) to confirm the growth of only the Gram-negative bacillus (E. coli).

Data for the analysis were obtained from these procedures. The descriptive analysis of the data was done by absolute frequency and relative frequency (percentage). Fisher's exact test was applied using SAS 2003 statistical software (SAS Institute Inc., Cary, NC, USA). The significance level was set at $5 \%$.

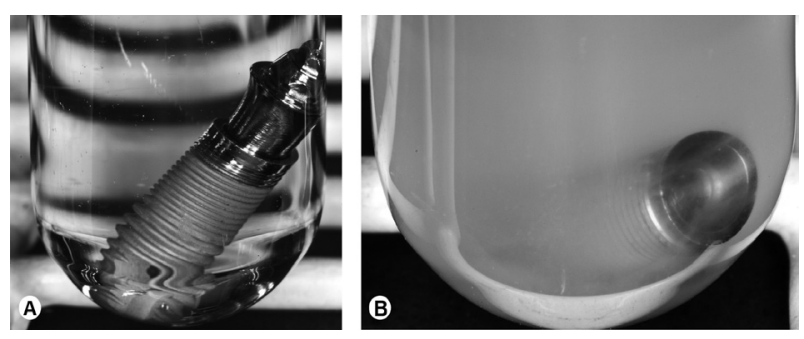

Figure 3. Macroscopic analysis of the tubes. A: tube without contamination; B: Contaminated tube with sediment at the bottom. 


\section{Results}

Contamination of the culture medium was confirmed by clouding or sediment at the bottom of the tubes (Tables 2 and 3). No clouding was observed in any of the tubes containing microbrushes used to control external contamination of the implants in Groups 1, 2 and 3.

Table 2 shows the result of bacterial contamination of the studied tubes, with values expressed as percentages. A statistically significant difference $(p<0.05)$ was observed in the number of contaminated implants for Group 2.

\section{Discussion}

In this in vitro study, two morse taper implant models were compared. One of the models was locked only by friction with a no-screw placement connection where the tightening action takes place due to the close contact and mechanical lock only by friction (Group 1). Abutments of 1-2 conicity degree were used, which allows bacterial seal with microgap reduction. The others abutments (Groups 2 and 3) used a screw and internal wall angle of 13 degrees. Although it is unknown whether this connection would remain intact without the retaining screw, the literature reports that the combination of two stabilizing components, morse taper and screw, resulted in a stable, strong and predictable connection. These characteristics should also allow bacterial seal and microgap reduction $(14,16)$.

The used methodology was similar to that employed

by Jansen et al. (8), while attempting to solve or minimize certain problems such as external contamination, caused by leakage of the $E$. coli solution used. In frictional implants, even when the volume of the suspension is very small, the prosthetic abutment can work as an embolus during activation, resulting in leakage of the solution. Taking this inconsideration, contamination was done using solid colonies of $E$. coli grown in $\mathrm{BHI}$ agar and transported directly from the culture plate to the most apical part of the prosthetic abutments. This could enable a more effective control of implant fitting platform contamination, eliminating the possibility of external contamination by leakage.

During placement of the prosthetic abutments on the implants, all manufacturer's recommendations were observed and strictly followed.

In the pilot study, the manufacturer's recommended $20 \mathrm{~N} . \mathrm{cm}$ torque was used, but as widespread and rapid contamination of the culture media had already been observed. Therefore, it was decided that different torques would be used in order to evaluate whether the torque recommended by the manufacturer was sufficient to promote sealing.

In tightening the abutment screw, a compressive force that promotes the frictional fit between the homologous surfaces is generated, and consequently a hermetic sealing. This phenomenon may cause an increase in the detorque values of the abutment screws compared to closing torque, causing a "cold welding" $(14,16,19,20)$. The higher the applied torque, the greater the preload value, leading to an improvement of bonding strength and true welding between the components $(14,16)$. The tightening force exerted in the screw must be within its elastic limit. However, in the present study, a 30 N.cm closing torque was applied (Group 3) which could be incompatible with the

Table 3. Frequency (\%) of contaminated implants

\begin{tabular}{lccc}
\hline Implants & Contaminated & Non-contaminated & Fisher's exact test \\
\hline Group 1 & $3(20 \%)$ & $12(80 \%)$ & \\
Group 2 & $9(60 \%)$ & $6(40 \%)$ & 0.000615 \\
Group 3 & $0(0 \%)$ & $15(100 \%)$ & \\
\hline
\end{tabular}

Group 1: 15 implants with mini-abutments tightened by friction and without no screws. Group 2: 15 implants with screw-tightened abutments subjected to 20 N.cm of closing torque. Group 3: 15 implants with screw-tightened abutments subjected to $20 \mathrm{~N} . \mathrm{cm}$ of closing torque. $p<0.05$ indicates a statistically significant difference. capacity of the solid components (micro-unit abutment) provided by the manufacturer, as well as the hexagonal fit of the screwdriver, since a 20 N.cm torque is recommended. It has been observed that some abutments used in the pilot study, stripped when receiving a $30 \mathrm{~N}$.cm closing torque. Theoretically they should withstand up to five times the recommended torque, but the hexagonal fit did not withstand the increasing torque without deforming. These observations may suggest that 
a square shape could be more adequate for this purpose.

After the 14-day observation, the culture medium contamination was significant for Group 2 implants, which received a $20 \mathrm{~N} . \mathrm{cm}$ torque, while those that received a 30 N.cm torque (Group 3) did not show any contamination. For Group 1 implants, the difference was not statistically significant.

These results support the idea that morse taper prosthetics can provide bacterial sealing, as long as "cold welding" is obtained between the components $(14,16,19)$. It is plausible to state that if bacteria cannot overcome the connection between the prosthetic abutment and the implant from the inside out, these microorganisms would also be unable to transpose this area in the opposite direction.

It seems quite clear that the applied 20 N.cm torque was not sufficient to cause this phenomenon and that the morse taper implants without screws (Group 1) and with screws inserted with a 30 N.cm torque (Group 3), showed similar behavior in bacterial permeability.

Evaluation of in vitro bacterial sealing ability may be taken into account when choosing systems and components. Nevertheless, in spite of the present results, further studies must be performed to eliminate variables that left certain questions unanswered, such as the standardization of the quantity of bacteria for contamination, in order to achieve a parameter to compare the systems used to gauge the required time for analyzing the culture medium contamination. It would be also interesting to evaluate the mechanical load after contamination and the fit between the abutments and implants. This procedure would simulate chewing cycles that may contribute to the increase in frictional resistance between the components, resulting in an improved seal (20). The evaluation of the detorque values of the connections using screws could also be considered in order to relate the existence of "cold welding" and the observed sealing $(14,16,19,20)$.

However, it is clear that certain aspects should be observed when morse taper implants are studied. The use of solid colonies of $\mathrm{E}$. coli is recommended for in vitro studies instead of suspension, and contamination should be done directly on the apical part of the prosthetic abutment instead of the inner part of the implant.

In addition, the recommended closing torque by the manufacturer ( $20 \mathrm{~N} . \mathrm{cm})$ should be re-evaluated considering the obtained results, as well as the elastic limit and fitting shape of the used solid components.

Based on the evaluation of the results obtained in this study, it may be concluded that there was no statistically significant difference in in vitro bacterial sealing between Groups 1 and 3 . The difference in closing torque altered the in vitro sealing ability of the tested abutments, with greater contamination for components that received a closing torque of 20 N.cm.

\section{Resumo}

0 objetivo deste estudo foi avaliar comparativamente, por meio de análise microbiológica in vitro, a capacidade de selamento bacteriano de dois modelos de implante de encaixe morse. Foram utilizados 15 implantes com travamento de seus respectivos mini-pilares por fricção, sem auxílio de parafuso (Grupo 1) e 30 implantes com travamento de seus respectivos mini-pilares sólidos reforçado pela presença de parafuso, sendo que 15 destes implantes receberam torque de inserção de 20 N.cm (Grupo 2) e o restante $30 \mathrm{~N} . c m$ (Grupo 3). A análise microbiológica foi realizada utilizando colônias de Escherichia coli transportadas diretamente da placa de cultivo para o componente protético. Os implantes friccionais (Grupo 1) foram ativados por meio do dispositivo bate conexão e para os aparafusados foi usada a chave de torque (Grupos 2 e 3 ). Cada conjunto de pilar/implante foi imerso em tubos de ensaio contendo $5 \mathrm{~mL}$ de caldo $\mathrm{BHI}$ (Brain-Heart Infusion) e incubados a $37{ }^{\circ} \mathrm{C}$ durante 14 dias com verificação diária de presença de contaminação. Foi observada diferença estatisticamente significante, com relação ao número de implantes contaminados. Para os implantes do Grupo 2, houve maior contaminação $(60 \%, p<0,05)$, não sendo observada diferença significativa entre os outros grupos (Grupo $1=20 \%$ e Grupo $3=0 \%$ ). Conclui-se neste estudo que não houve diferença estatistica significante quanto ao selamento bacteriano in vitro entre os Grupos 1 e 3. A diferença de torque de inserção alterou a capacidade de selamento in vitro dos pilares testados, sendo observada uma maior contaminação para os componentes que receberam o torque de 20 N.cm.

\section{Acknowledgements}

The authors wish to thank Gilca Saba for her excellent technical expertise and assistance.

\section{References}

1. Heydenrijk K, Meijer HJ, Van der Reijden WA, Raghoebar GM, Vissink $A$, Stegenga B. Microbiota around root-form endosseous implants: a review of the literature. Int J Oral Maxillofac Implants 2002;17:829838.

2. Broggini N, McManus LM, Hermann JS, Medina RU, Oates TW, SchenK RK, et al.. Persistent acute inflammation at the implant-abutment interface. J Dent Res 2003;82:232-237.

3. Mombelli A, Decaillet F. The characteristics of biofilms in peri-implant disease. J Clin Periodontol 2011;38: 203-213.

4. Gross M, Abramovich I, Weiss El. Microleakage at the abutmentimplant interface of osseointegrated implants: a comparative study. Int J Oral Maxillofac Implants 1999;14:94-100.

5. Orsini G, Fanali S, Scarano A, Petrone G, Di Silvestro S, Piatelli A. Tissue reactions fluids and bacterial infiltration in implants retrieved at autopsy: a case report. Int J Oral Maxillofac Implants 2000;15:283-286.

6. Zipprich $\mathrm{H}$, Weigl $\mathrm{P}$, Lauer HC, Lange B. Micro-movements at the implant-abutment interface: measurements, causes and consequences. Implantologie 2007;15:31-45.

7. Rimondini L, Marin C, Brunella F, Fini M. Internal contamination of a 2-component implant system after occlusal loading and provisionally luted reconstruction with or without a washer device. J Periodontol 2001;72:1652-1657.

8. Jansen VK, Conrads G, Richter E. Microbial leakage and marginal fit of the implant /abutment interface. Int J Oral Maxillofac Implants 1997;12:527-540.

9. Aloise JP, Curcio R, Laporta MZ, Rossi L, Silva AMA, Rapoport A. Microbial leakage through the implant-abutment interface of morse taper implants in vitro. Clin Oral Impl Res 2010;21:328-335.

10. Ricomini Filho AP, Fernandes FSF, Straioto FG, Silva WJ, Del Bel Cury AA. Preload loss and bacterial penetration on different implant-abutment 
connection systems. Braz Dent J 2010;21:123-129.

11. Dias EC, Bisognin ED, Harari ND, Machado SJ, Silva CP, Soares GDA, et al.. Evaluation of implant-abutment microgap and bacterial leakage in five external-hex implant systems: an in vitro study. Int J Oral Maxillofac Implants 2012;27:346-351.

12. Steinebrunner $L$, Wolfart S, Bössmann K, Kern M. In vitro evaluation of bacterial leakage along the implant-abutment interface of different implant systems. Int J Oral Maxillofac Implants 2005;20:875-881.

13. Harder S, Quabius ES, Ossenkop L, Kern M. Assessment of lipopolysaccharide microleakage at conical implant-abutment connections. Clin Oral Invest 2012;16:1377-1384.

14. Binon P. Implants and components: entering the new millennium. Int J Oral Maxillofac Implants 2000;15:76-94.

15. Dibart $\mathrm{S}$, Warbington M, Su MF, Skobe Z. In vitro evaluation of the implant abutment bacterial seal: The locking taper system. Int J Oral Maxillofac Implants 2005;20:732-737.

16. Bozkaya D, Muftu S. Mechanics of the taper integrated screwed-in (TIS) abutments used in dental implants. J Biomec 2005;38:87-97.

17. Mangano C, Mangano F, Piattelli A, lezzi G, Mangano A, La Colla L. Prospective clinical evaluation of 1920 Morse taper connection implants: results after 4 years of functional loading. Clin Oral Impl Res 2009;20:254-261.

18. Sannino G, Barlattani A. Mechanical evaluation of an implantabutment self-locking taper connection: finite element analysis and experimental tests. Int J Oral Maxillofac Implants 2013;28:e17-e26.

19. Norton MR. Assessment of cold welding properties of the internal conical interface of two commercially available implant systems. J Prosthet Dent 1999;81:159-166.

20. Zielak JC, Rorbacker M, Gomes R, Yamashita C, Gonzaga CC, Giovanni AF. In vitro evaluation of the removal force of abutments in frictional dental implants. J Oral Implantol 2011;37:519-523.

Received February 1, 2013 Accepted February 12, 2014 